\title{
CAMbridge
}
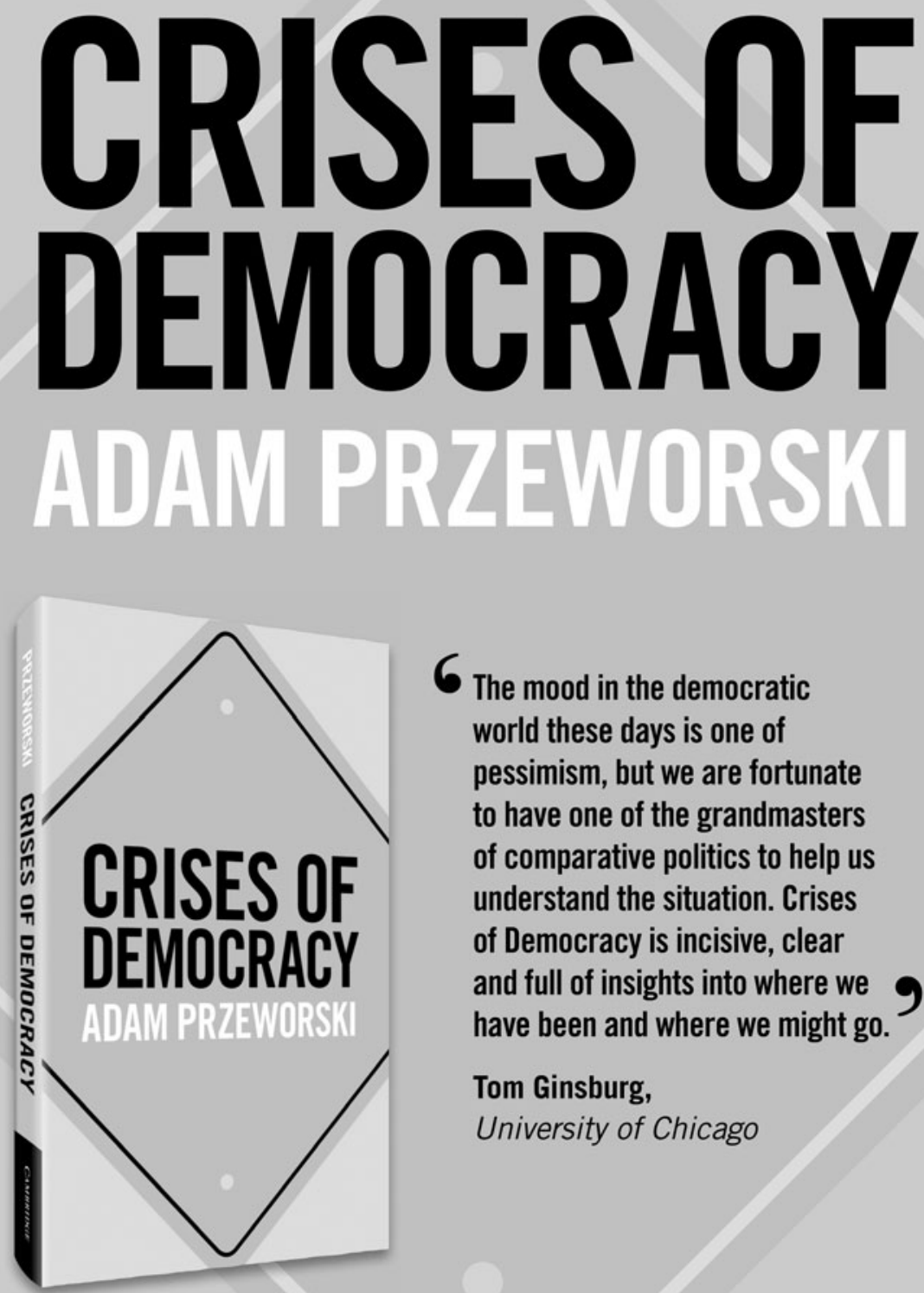

6 The mood in the democratic world these days is one of pessimism, but we are fortunate to have one of the grandmasters of comparative politics to help us understand the situation. Crises of Democracy is incisive, clear and full of insights into where we 9 have been and where we might go.

Tom Ginsburg, University of Chicago 
Notes for contributors

Instructions to authors for the submission of manuscripts to Review of International Studies can be found online at cambridge.org/RIS.

CAMBRIDGE UNIVERSITY PRESS

University Printing House, Shaftesbury Road, Cambridge CB2 8BS, United Kingdom

1 Liberty Plaza, Floor 20, New York, NY 10006, USA

477 Williamstown Road, Port Melbourne, VIC 3207, Australia

Ruiz de Alarcón 13, 28014 Madrid, Spain

Dock House, The Waterfront, Cape Town 8001, South Africa

This journal issue has been printed on $\mathrm{FSC}^{\mathrm{TM}}$-certified paper and cover board. FSC is an independent, non-governmental, not-for-profit organization established to promote the responsible management of the world's forests. Please see www.fsc.org for information.

Printed in the United Kingdom by Bell \& Bain 


\section{Review of}

\section{International}

\section{Studies}

\section{VOLUME 46 | ISSUE 1 | JANUARY 2020}

Editorial

\section{ARTICLES}

'Practice time!' Doxic futures in security and defence diplomacy after Brexit

\section{Øyvind Svendsen}

Interests, ideas, and the study of state behaviour in neoclassical realism

\section{Gustav Meibauer}

Traversing the soft/hard power binary: the case of the Sino-Japanese territorial dispute

\section{Linus Hagström and Chengxin Pan}

Internationalists, sovereigntists, nativists: Contending visions of world order in Pan-Africanism

\section{Rita Abrahamsen}

Images, emotions, and international politics: the death of Alan Kurdi

\section{Rebecca Adler-Nissen, Katrine Emilie Andersen and Lene Hansen}

Punishing the violators? Arms embargoes and economic sanctions as tools of norm enforcement

\section{Jennifer L. Erickson}

Topological twists in the Syrian conflict: Re-thinking space through bread

\section{José Ciro Martínez}

'\#Refugees can be entrepreneurs too!' Humanitarianism, race, and the marketing of Syrian refugees

\section{Lewis Turner}

The costs of war: Condolence payments and the politics of killing civilians

\section{Thomas Gregory}

